IRSH 47 (2002), pp. 3-33 DOI: I0.1017/S0020859002000767

(C) 2002 Internationaal Instituut voor Sociale Geschiedenis

\title{
Introduction: De-industrialization and Globalization
}

\author{
CHRISTOPHER H. JOHNSON
}

THE RELATION BETWEEN DE-INDUSTRIALIZATION AND GLOBALIZATION

The problem of de-industrialization has undergone a decisive transmutation in the past two decades, roughly from the moment when it was linked to proto-industrialization at the Budapest Economic History Conference in 198r. ${ }^{\mathrm{I}}$ Also interacting with the remarkable efforts of Immanuel Wallerstein and his colleagues who dated the formation of a "world economic system" from the expansion of European conquest and trade in the fifteenth and sixteenth centuries, its place in historical and sociological analysis rapidly transcended local concerns (such as the warmly received I 982 study by Bluestone and Harrison of the American "rust belt") and has become an element in the overall problematique of global capitalism. ${ }^{2}$ Only very recently, however, have the necessary studies (and hence theoretical perspectives) formed an appropriate critical mass to integrate the concept of de-industrialization fully into the long-term history of economic globalism. We are coming to understand that the phenomenon at the tip of the tongue of every head of state and the source of massive (and lethal) protest that came to be termed "globalization" in ordinary

I. See Franklin Mendels, "General Report, Eighth International Economic History Congress, Section A.2: Proto-industrialization: Theory and Reality”, Budapest, August 1982, and attached papers (photocopied reproductions). An excellent collection of articles selected from these papers appeared as Carlo Poni (ed.) Protoindustria, a special issue of Quaderni strorici, 52 (1983). Also central to the proto-industrialization debate was Peter Kriedte, Hans Medick, and Jürgen Schlumbohm, Industrialization before Industrialization (Cambridge, 1981).

2. Immanuel Wallerstein, The Modern World System: Capitalist Agriculture and the Origins of the European World Economy in the Sixteenth Century (New York, 1974); idem, Mercantilism and the Consolidation of the European World Economy (New York, I980); and idem, The Second Era of Great Expansion in the Capitalist World-Economy (San Diego, CA, 1989); Barry Bluestone and Bennett Harrison, The Deindustrialization of America (New York, 1982). An excellent analysis of the shortcomings of localized approaches appeared early in Robert Kuttner, The End of Laissez-Faire: National Purpose and the Global Economy after the Cold War (New York, I99I). More recently, the sober overviews of Robert Gilpin contest the extent to which globalization has overpowered national economic policy and national markets: Robert Gilpin, The Challenge of Global Capitalism: The World Economy in the 2 Ist Century (Princeton, NJ, 2000) and idem, Global Political Economy: Understanding the International Economic Order (Princeton, NJ, 200I). He nevertheless understands "de-industrialization" as an aspect of more general market shifts. 
parlance around $\mathbf{I} 990$ is hardly new and, most importantly, not simply a one-way street originating in the West.

An array of recent studies have demonstrated the remarkable variety of sophisticated practices and vast geographic scope of integrated trade networks that look suspiciously "capitalistic" pervading the borderlands of the Indian Ocean and the western Pacific from Kilwa to Kaifeng at a time when Europeans were just beginning to "invent" capitalism. ${ }^{3}$ The idea of "parallel development" between China and Europe for much of the second millennium, best argued by Kenneth Pomeranz and R. Bin Wong, seriously challenges Eurocentric notions of the origins of the modern economy. Particularly in terms of "extensive" agricultural growth and population balance, the vitality of international trade, the quality of handicraft manufacturing, and even technological inventiveness, there would be no way to predict, say in I 700, whether Europe or China would lead the way toward the industrial breakthrough. For Wong, the European advantage arose above all from the happy circumstance of accessible mineral-based energy production, while Pomeranz stresses the broader advantage of European New-World domination and its multiple consequences. ${ }^{4}$ And new work on India has definitively shown that the economy of the subcontinent, particularly the cotton textile region of the south, was booming in the later seventeenth and eighteenth centuries, stimulating not only British interest in tapping into its trade throughout the Indian Ocean-East Asian region, but also the British indigenous cotton industry - that famous "engine of modernization" - the pre-industrial organization of which was remarkably similar to the Indian business (which dwarfed the entire British textile manufacture until the nineteenth century). The Indian cotton industry was certainly harmed and its laborers impoverished by growing British colonial dominance, but it can hardly be said that India fell into a state of pure "dependency" as the interactive

3. Janet Abu-Lughod, Before European Hegemony: The World System AD 1250-1350 (New York, 1989) attracted the most attention. See also the ambitious Braudelian study by K.N. Chaudhuri, Asia Before Europe: Economy and Civilization of the Indian Ocean from the Rise of Islam to 1750 (Cambridge, 1990) as well as his earlier work, Trade and Civilization in the Indian Ocean (Cambridge, 1985). The pioneering work of Philip Curtin, Cross-Cultural Trade in World History (Cambridge, 1984), and Marshall Hodgson, Rethinking World History: Essays on Europe, Islam, World History, Edmund Burke III (ed.) (Cambridge, I993) should not be forgotten. A good collection is James Tracy (ed.), The Rise of Merchant Empires (Cambridge, 1990). On European primacy, see E.L. Jones, The European Miracle (Cambridge, 1987) and David Landes, The Wealth and Poverty of Nations: Why Some Are So Rich and Some So Poor (New York, 1998). See also the balanced analysis of Patrick Verley, L'échelle du monde: Essai sur l'industrialisation de l'Occident (Paris, 1997).

4. Kenneth Pomeranz, The Great Divergence: Europe, China, and the Making of the Modern World Economy (Princeton, NJ, 2000); R. Bin Wong, China Transformed: Historical Change and the Limits of European Experience (Ithaca, NY [etc.], I997). For a solid analysis of this new historiography, see Gale Stokes, "The Fates of Human Societies: A Review of Recent Macrohistories”, American Historical Review, I06 (2001), pp. 508-525. 
process of colonial contact enhanced opportunities for many Indian merchants, and indigenous entrepreneurs benefited from imported technologies in modernizing "traditional" industries, so offsetting to some extent the deluge of British imports. Similar arguments have been made for the (less intrusive) Dutch encounters with Chinese and Muslim merchants and indigenous landowners and rulers in Indonesia.'

The central argument in the new history of globalism is that while the European presence and military dominance clearly rerouted many economies of Asia, the latters' prior sophistication and scope was for the most part encroached upon rather than transformed, and that while some elements in those working populations were indeed more greatly exploited, others, mainly from the merchant and professional castes and classes, continued to do well and creatively integrated their earlier practices with those of the Europeans, while the latter did the same. This is not to say that these elements became stooges for the colonizers - and indeed we know well where the leadership of the anticolonial movements came from - but that they created a parallel economy, sometimes integrated with the European, sometimes not (the latter often emphasizing "traditional" methods and goods) and maintained their own trading networks, if often at the behest of Europeans. From this perspective, the "Asian miracle" of the second half of the twentieth century (though led indeed by the one nation that successfully resisted Western incursion), and an even brighter twenty-first century as China and India fully enter the global economy, seem less miraculous. Some, such as André Gunder Frank, even argue that the West's 200 years of power will, in the long run, seem like a mere blip on the historical radar screen. ${ }^{6}$

It will be noted that the previous discussion concerns Asia. Similar arguments cannot be so easily sustained for encounters with Europeans in the Americas and most of Africa, as disease in one and the slave trade in the other permanently undermined pre-existing, often vital economies.

5. Prasannan Parthasarathi, The Transition to a Colonial Economy: Weavers, Merchants, and Kings in South India (Cambridge, 200I); Claude Markovits, The Global World of Indian Merchants, 1750-1947 (Cambridge, 1999); Tirthankar Roy, Traditional Industry in the Economy of Colonial India (Cambridge, 2000); Peter Harnetty, “'Deindustrialization Revisited': The Handloom Weavers of the Central Provinces of India, c. I 800-1947", Modern Asian Studies, 25 (1991), pp. 455-510; Kristof Glamann, The Dutch Asiatic Trade, 1620-1740 (The Hague, 1981); Charles Boxer, The Dutch Seaborne Empire, I600-I800 (New York, 1965); Maurice Aymard (ed.), Dutch Capitalism and World Capitalism (Cambridge, 1982). On China, see Michael Godley, The Mandarin Capitalists from Nanyang: Overseas Chinese Enterprise in the Modernization of China, I893-I9II (Cambridge, I98I) For the notion of the "indigenization of modernity", see Marshall Sahlins, "Goodbye to Tristes Tropes: Ethnography in the Context of Modern World History", Journal of Modern History, 65 (I993), pp. I-25.

6. Frank is the most extreme revisionist and overstates his case, but is very much worth reading: André Gunder Frank, ReOrient: Global Economy in the Asian Age (Berkeley, CA, I998). 
Although the peoples of the preconquest western hemisphere often constructed huge trading areas and developed marvelous production techniques (think of Cahokia near the confluence of the Ohio and Mississippi rivers trading Keweenau copper goods for Gulf shell products or the vast Inca Empire connected by paved roads), they obviously never participated in a world economy, and indeed, insuperable barriers prevented anything close to continental integration. As for Africa, certainly the northern and eastern coastal regions were vital elements (and key connectors) of the Muslim world systems of the Mediterranean and Indian Oceans, while powerful West African states provided the gold, via Arab traders across the Sahara and the Sudan, that allowed Europeans and others to buy coveted goods such as silks and porcelains from the East and contributed mightily to (especially) Chinese economic growth during the Yuan and early Ming. But all that changed after the disastrous sixteenth century. The survivors entered relationships with Europeans that were transformative and dependent, even for the most successful, such as the fur traders of the American north or the slave traders of Asante and Dahomey. ${ }^{7}$ And indeed, as noted, Pomeranz, in his search for advantages of Europe over China, sees New World dominance and its consequences for Africans on both sides of the Atlantic as the critical difference. There does remain something to be said for dependency theory, but its applications are specific and its scope too narrow to stand as a general theory of the global economy. ${ }^{8}$

What has all this to do with de-industrialization? In understanding its causes and place in history, a great deal, in understanding its consequences, less perhaps, though for its victims to confront seriously its inequities and mount meaningful protest, the globalist framework seems to me essential.

Is it legitimate to include prefactory instances of industrial decline under

7. On the deep historical advantages of Eurasia vis-à-vis the rest of the world see Jared Diamond, Guns, Germs, and Steel: The Fates of Human Societies (New York, 1997). In a vast literature, see Eric Wolf, Europe and the People without History (Berkeley, CA, 1982); Stuart Schwartz (ed.), Implicit Understandings: Observing, Reporting, and Reflecting on the Encounters Between Europeans and other Peoples in the Early Modern Era (Cambridge, 1994); Alvin M. Josephy, Jr (ed.), America in 1492: The World of the Indian Peoples Before the Arrival of Columbus (New York, 1992); Alfred Crosby, Ecological Imperialism: The Biological Expansion of Europe, 900-1900 (Cambridge, 1986); Walter Rodney, A History of the Upper Guinea Coast, I 545-I 800 (Oxford, I970); Robin C.C. Law, The Impact of the Slave Trade on a West African Society (Oxford, I99I); Ira Berlin, Many Thousands Gone: The First Two Centuries of Slavery in North America (Cambridge, MA, 1998).

8. Pomeranz, Great Divergence, ch. 6; the classic theoretical statement of dependency appeared in André Gunder Frank, Capitalism and Underdevelopment in Latin America (New York, 1969). The economics of dependency are studied with insight by Daniel Headrick, Tools of Empire (Oxford, 1981) and idem, The Tentacles of Progress (Oxford, 1988), though recent research on India needs to be integrated with this work, which states the theme too baldly, perhaps. 
the rubric "de-industrialization"?9 I will argue, and hope to demonstrate via examples given below, that it is not only legitimate, but essential if one is to integrate the notion into general economic theory. The word itself seems to be a recent one and originally referred to quite active steps taken to reduce or eliminate the industrial base of regions and countries by the Nazis. It was then picked up by the Allies in discussing possible postwar retribution against Germany. As a term for a conjunctural, structural process, according to the Oxford English Dictionary, it enters British usage in the I970s as the discussion of massive plant closings and regional collapse of Fordist industries, not only in the UK but on the continent, preoccupied the public. US usage for the same quickly followed, and was canonized by Bluestone and Harrison's Deindustrialization of America in 1982. In French, use of désindustrialisation for a structural process may well have been coined by Raymond Dugrand in 1963 in his classic study of the rise of the vine and its consequences for urban life in Languedoc in the later nineteenth and twentieth centuries. The term was thus originally established to describe the decline of modern, factory industry and generally in relation to the limits in the West of mass production as competition from elsewhere and plant relocation overwhelmed superannuated, high-wage industries and specific sites. ${ }^{\circ}$

But, by the early i 980 s, in laying out the theory of proto-industrialization, Franklin Mendels, Pierre Deyon, and the Göttingen team of Hans Medick, Peter Kriedte, and Jürgen Schlumbohm were speaking of areas with previous industrial concentration based in handicraft production that failed to make the transition as "de-industrialized". Such regions have in fact turned out to be so numerous that the "theory" of protoindustrialization (if not the reality of industrial ruralization in Europe and India and China from the late Middle Ages to the eighteenth century) predicting the conditions for machine-industrialization has proven unconvincing, though what a pot it stirred! D.C. Coleman, in the initial foray against the theory, pointed out that of the ten British regions (though he also challenges the very idea of "region") where large amounts of textiles were produced by hand mainly by rural people, a majority, six, did not make the transition, or as he mockingly puts it, they

9. Incidentally, American usage has suppressed the hyphen, thus elevating the term, in the language of the Oxford English Dictionary, to an "older and more important word", something the OED was not prepared to do in I989. I have continued the British usage here. See D.C. Coleman, "Proto-industrialization: One Concept Too Many?", Economic History Review, 36 (1983), pp. 435-448.

ıo. Oxford English Dictionary (2nd edn), Compact (Oxford, I989), p. 392; Raymond Dugrand, Villes et campagnes en Bas-Languedoc (Paris, 1963). Discussions of India during the colonial period also use the term and predate these examples. Daniel Thorner, "De-industrialization' in India, I88I-193I”, in Contributions, Communications: First International Conference of Economic History, Stockholm, 1960 (Paris [etc.], I960), pp. 217-226. 
"deprotoindustrialized". ${ }^{\text {II }}$ German historians, in sorting out regional economic trajectories in the nineteenth century, opted in the I970s for the term "Reagrarisierung" to describe such transitions - a phenomenon that happened in many places where, while the shift back to the land might have been hard on certain highly concentrated industrial localities, the new commercially oriented agriculture provided sufficient livelihoods for the bulk of the population in the long run, and even encouraged in-migration, as was, for example, the case in Languedoc. ${ }^{\mathrm{I2}}$

There are more than enough similarities between modern and early modern industries in both town and country (non-European as well) to include them in the history, and the possible theorization, of deindustrialization. And, as the integrated approach of the Germans cited above and our work on Languedoc show, exactly where the line between handicraft industry and factory industry lies is difficult to ascertain. Indeed, as we now know, there were so many "alternatives to mass production" throughout the history of "modern industry" that "coexistence" rather than a dominant form may well have been typical. Agriculture itself can be a spur to industrial growth, both small- and large-scale, as the history not only of re-agrarianized regions but of entire nations, demonstrates. ${ }^{13}$ So the variables multiply. The reasons for including the entire industrial experience of Eurasia from I 200 on (even earlier to include the Abbasid economic network centered in Baghdad) in the assessment of de-industrialization seem straightforward. As in the modern (and "postmodern") era, the essence of widespread systems was a substantial trade in manufactured goods whose rhythms of productions responded to market fluctuations far and near: fluctuations in demand, to be sure, but also in capital and labor markets, and punctuated as well by crises generally based in agricultural price increases (food was the "energy" of hand production - the equivalent of modern fossil fuels) but also in goods overproduction and financial market panics.

I I. Coleman, "Proto-industrialization", pp. 445-447.

I 2. On German historiography, see W.R. Lee, "Economic Development and the State in Nineteenth-Century Germany”, Economic History Review, 4I (1988), pp. 346-367; P. Fried, "Reagrarisierung in Südbayern seit dem i9. Jahrhunderts", in Hermann Kellenbenz (ed.), Agrarisches Nebengewerbe und Formen der Reagrarisierung im Spätmittelalter und 19/20. Jabrbunderts (Stuttgart, I975); H. Kreiswetter, "Erklärungsversuche zur regionalen Industrialisierung in Deutschland im I9. Jahrhundert", Vierteljahrschrift für Sozial- und Wirtschaftsgeschichte, 67 (1980), pp. 305-333. On Languedoc, see Dugrand, Villes et campagnes; Leslie Page Moch, Paths to the City: Regional Migration in Nineteenth-Century France (Thousand Oaks, CA, 1983); Christopher H. Johnson, The Life and Death of Industrial Languedoc (Oxford, I995).

I 3. Charles Sabel and Jonathan Zeitlin, "Historical Alternatives to Mass Production", Past and Present, I08 (1985), pp. I33-176. Alan Kulikoff, The Agrarian Origins of American Capitalism (Charlottesville, VA, I992); Thorkild Kjaergaard, The Danish Revolution, I500-I800 (Cambridge, I994); Kristoff Glamann, "Industrialization as a Factor in Economic Growth in Denmark since 1700”, Stockholm Conference, 1960, pp. I I5-I 28. 
De-industrialization, as today, might be stimulated by crises, but, as today, had more profound roots. The most typical pattern would seem to have the following features: declining demand due to shifts in the perceived price/quality ratio as coupled with a range of cultural factors, including the slippery one of taste. High prices would have to do with wage levels; productivity shortfalls with worker dissatisfaction or ennui; decline of quality and/or lack of innovation could be linked to manufacturer and marketer decisions to stick with "tried and true" techniques that spelled success in the past, thus failing to respond to shifts in taste; increasing costs of raw materials (even in labor-intensive manufacturing, supply costs outweighed labor, especially in textiles) could be the result of price-fixing or gouging by capitalists, and also withdrawal of capital resources by outside investors (usually a second-tier response after sales decline was under way, but could also occur with the emergence of much more attractive investment opportunities). Another element in the gravity of de-industrialization for a region is its overspecialization in one product. Remaining in the purely economic realm, none of these factors would necessarily lead to decline of a product or region, if competitive goods did not exist. These might not even be in the same product line (cotton's victory over linen is the readiest example). But in the worldtrading systems under discussion, competition is always present: it is, by definition, its lifeblood. The competitors, of course, would possess advantageous conditions regarding most of these economic factors.

If the foregoing could be a description of what happened in the American automobile industry in the later twentieth century, it works equally well for Flemish woolens in the earlier fourteenth, diverse north Italian industries in the mid-seventeenth, Dutch papermaking in the later eighteenth, or the dual (pre-machine/post-machine) decline of lower Languedoc in the later eighteenth and then mid-nineteenth centuries. It also works for earlier machine-industrial de-industrializations, the British "climacteric" of the later nineteenth century, and the decline of New England textiles in the earlier twentieth, thus fully demonstrating the relevance of the concept of de-industrialization to pre-machine industry experiences. We should also consider the fate of the early modern Indian cotton industry in this same context. These examples were all enormously successful in their heyday. Just as market forces within a world system made them, they also contributed to breaking them.

But, this is not, was not, and will not be a pure Smithian world. Competition is always modified by politics. It is ironic that the putative fathers of economics as a natural science, the names beloved by contemporary neoliberals, called their work "political economy"; unlike their latter-day disciples, they understood that policy and economy could not be untangled. How they are tangled was their concern and is (should be) what economic historians must seek to understand. The politics of 
de-industrialization were as critical to the handicraft industrial world as to the machine or informational ages. The most obvious influences from the political realm are conquest, war, and diplomacy, having both conscious and unintended effects. More difficult to ascertain, however, are the effects of political negotiations and day-to-day decisions of sovereign authorities bearing upon regions already threatened by "natural" shifts in the economy. Several of the papers in this collection deal brilliantly with precisely this issue and my own study of nineteenth-century Languedoc is subtitled "the politics of de-industrialization". Were politics important in earlier de-industrializations? Indeed, and perhaps even more so. In an age where, in the words of Josiah Child, "power and profit ought jointly to be considered" and the notion of laissez-faire was yet undiscovered, political decisions by sovereign authorities could not only enhance industrial decline, but precipitate it. ${ }^{\mathrm{I}}$

A third, and more problematic, factor influencing the fates of industrial economies can be termed "ecological". At the most basic level, this refers to the availability of resources, natural and human, and hence the significance of disease in history (as it attacks both human and nonhuman life), the role of climatic change, and, of course the overutilization of finite (and/or harmful) resources. This is an area of intense historiographical interest today that goes far beyond the subject at hand, but we are indeed reminded of its significance for both the trajectory of the world economy and the power of politics to alter it as we watch the current American administration, in this age of threats to US hegemony, back away from all the international accords envisioning control of such potential disasters.

The historical record is, of course, full of instances where ecological catastrophes precipitated economic decline. But, with the notable excep-

I4. On Child, see Barry Supple, Commercial Crisis and Change in England, I600-I642 (Cambridge, 1964). The American experience is often cited as a prime example (versus, say, France or Prussia) of economic growth due to "hands off" policies of government. This may well have been the case with regard to regulation for social protection, but government subsidization of growth is as American as apple pie (unless you are a Native American). Witness selective, often two-faced, tariff protection throughout US history; the great land giveaways of the Homestead Act and railroad construction; the "GI Bill of Rights"; or the interstate highway system. For trenchant analysis of the role of the state in American economic growth, see the works of Robert L. Heilbroner, especially the overviews, The Making of Economic Society, sth edn (Englewood Cliffs, NJ, 1975) and (with Aaron Singer), The Economic Transformation of America: I600 to the Present, 2nd edn (San Diego, CA, I984). On the origins of "big business", see Alfred D. Chandler, The Visible Hand: The Managerial Revolution in American Business (Cambridge, MA, 1977). See, for Europe, Betty Behrens, "Government and Society", in E.E. Rich and C.H. Wilson (eds), The Cambridge Economic History of Europe, vol. 5, The Economic Organization of Early Modern Europe (Cambridge, 1977), pp. 549-620; and Gregory Clark, "The Political Foundations of Modern Economic Growth: England, I540-1800", Journal of Interdisciplinary History, 26 (1996), pp. 563-588. 
tion of history's greatest victory of germ over human, the "American holocaust" of the sixteenth century, most have served in the long run for renewal and reoriented growth. European economic historians thus couple the horrible "solutions" to fourteenth-century overpopulation (the falling temperatures and the Black Death) with the end of serfdom in the West, increased yields, and the agrarian stimulation of growth of trade and manufacturing. Early modern deforestation in western Europe threatens shipbuilding and metals refining only to advance the American timber industry (the colonies' biggest export) and lead to coal-coking technology. The pébrine causes the collapse of the French silk industry, but gets Lyon off its single track to a multifaceted economic renaissance that continues to this day (not to mention intense interest in a certain area of southeast Asia). The phylloxera ravages European vines and stimulates, via the use of American rootstock, one of the great economic success stories of the twentieth century. ${ }^{\text {IS }}$ In general, then, one must be skeptical of arguments that privilege ecological factors in the history of de-industrialization, though obviously demographic disaster, the mining out of resources, natural catastrophes, and the like can have significant short-run effects.

\section{THREE CASES OF EARLY DE-INDUSTRIALIZATION}

Let us now examine three cases of early de-industrialization with an eye toward parallels with examples in this volume and other contemporary instances, to return finally to perhaps America's most famous modern story, the Detroit automobile industry. The purpose of this exercise is to explore the comparability of the phenomenon over time.

The earliest major (European) case of regional economic decline occurred in the great Flemish woolen industry during the late thirteenth

I 5. David Stannard, American Holocaust: The Conquest of the New World (Oxford, I992). On the issue of the significance of the Black Death in the late medieval "crisis of feudalism", one must take care not to fall into demographic determinism, but there can be no doubt that it was a contributing factor in the restructuring of economy and society in western Europe during the fourteenth and fifteenth centuries. In the enormous literature, see Wilhelm Abel, Agrarian Fluctuations in Europe from the Thirteenth to the Twentieth Centuries (New York, I980); Guy Bois, La crise du féodalisme (Paris, 1976); T.H. Ashton and C.H.E. Philpin (eds), The Brenner Debate: Agrarian Class Structure and Economic Development in Pre-Industrial Europe (Cambridge, 1987); R.G. Albion, Forests and Sea Power: The Timber Problem of the Royal Navy (Hamden, CT, 1926, repr. 1965); John McCusker and Russell Menard, The Economy of British America, $1607-1789$ (Chapel Hill, NC, 1985); G. Hammersly, "The Charcoal Industry and Its Fuel, I 540-1750”, Economic History Review, 26 (1973), pp. 593-613. Yves Lequin, Les ouvriers de la région lyonnaise (I848-19I4), 2 vols (Lyon, I977); Marcel Lachiver, Vins, Vignes et vignerons: histoire du vignoble français (Paris, 1988); Harry W. Paul, Science, Vine, and Wine in Modern France (Cambridge, 1996). 
and fourteenth centuries. ${ }^{16}$ By the early thirteenth century, the flourishing cities of Flanders had developed an excellent fulled broadcloth produced in an urban putting-out system dominated by great merchants who nevertheless had to negotiate agreements with producer guilds (above all the "blue-nailed" weavers). The industry's success was rooted in a far-reaching trade system, drawing its raw wool from the best source available, England (especially its monasteries), processing it in the humid Flemish lowlands, and shipping it through the fairs of Champagne via exchange with Italian merchants (mainly Genoese) who then distributed the cloth throughout the Mediterranean and trading again, in the east, with Arabs who sold it throughout their vast "world system". The sources of its decline, which in terms of overall sales only dates from the I 3 Ios but can be traced more deeply, include elements of all three factors - economic conjuncture, politics, and ecology - and seem impossible to grid into a causal pattern. But all resonate with contemporary experience. Flanders, like the midwestern American auto industry centered in Detroit, received its raw materials from elsewhere, benefiting due to its location from cheap maritime transport of bulky goods as well as inland trans-shipment of lighter materials. ${ }^{17}$ This vulnerability exposed the industry to competition

16. The classic study, of course, is Henri Pirenne's Belgian Democracy (I9I5). The edition consulted here is Early Democracies in the Low Countries, J.V. Saunders (transl.) with an introduction by John H. Mundy (New York, 1963). Pirenne has been revised significantly, largely along the lines suggested by Mundy: "Was the corporatist and statist economy of the late middle ages and early modern times quite as uninventive and reactionary as Pirenne described it? [...] May one properly suppose [...] that economic enterprise, when free and unregulated by princes, government or social corporatism, necessarily provides the principal or sole means for the advancement of human liberty?” (p. xxvi). These remarks reflect the beginning of a massive rethinking of the history of capitalism that had a difficult row to hoe because both liberals and most Marxists, who dominated twentieth-century historiography until fairly recently, subscribed to this vision. One of the main themes of my analysis in this essay is its emphasis on the political, social, and cultural variables that always interact with economic forces to shape human life, whether positively or negatively. Another relevant interpretation that one still sees in textbooks is E.M. Carus-Wilson's (Medieval Merchant Venturers, London, 1954) explanation of emerging English competitive advantage vis-à-vis Flanders in the woolen cloth business supposedly caused by the fulling mill, an argument canonized by Jean Gimpel in The Medieval Machine: The Industrial Revolution of the Middle Ages (Harmondsworth, 1977). Recent work has criticized her studies by pointing out that the areas of the West Country where she found so many mills in the thirteenth century produced precious few cloths. The whole argument needs to be pushed forward a century and one needs to understand that, technically, water pressure is a matter of correctly constructed weirs and sluices, not (necessarily) fast-flowing streams. This does not mean, however, that English policy on wool as well as woolens competition and continental military action did not figure as factors in Flemish decline in the fourteenth century.

I7. Until the I950s, most of Detroit's materials came from US areas largely accessible by water. Ford, of course, made his cars at the Rouge plant from scratch: ore from northern Minnesota, coal from Pennsylvania, wood from the (largely his own) forests of the Upper Peninsula (a significant component until the I930s), leather from mid-Western tanneries, while the other companies bought steel from local mills as well as Pittsburgh, Cleveland, and Gary and semifinished components from innumerable suppliers in metropolitan southeastern Michigan 
from the supplier itself and England did not disappoint, beginning its shift to woolen production in qualities directly competing with Flemish cloth by the mid-thirteenth century, and accompanied by a certain "buy English" mentality. The general prosperity of the international cloth trade and the weakness of the English crown kept the potential threat at bay. But in the early I 270s, Prince Edward, later King Edward I, unfurled a policy seeking to revitalize England's continental power that focused centrally on weakening Flanders and specifically on ending the "Flemish ascendancy", the inordinate power of Flemish merchants in England over the wool market. This involved a protracted struggle of seizures and bans, culminating in I274-I275 in a ban on all exports of wool, since plenty of wool reached Flanders illegally or via non-Flemish merchants and venues. Such policies could not last forever, and Edward and the heir apparent, Count Guy de Dampierre, reached agreement for the reopening of the wool trade and the importation of Flemish cloth (made from English wool, of course). But things were not at all the same, as Italians (along with Cahorsians and English merchants themselves) became increasingly vital middlemen at the expense of the Flemish. The net result was an increase in the price Flemish manufacturers paid for their wool and growing doubts in England about the purchase of Flemish-made goods. Thus, the first important step in the long process of decline seems largely political. ${ }^{18}$

But there also was occurring a shift in Mediterranean and Near-Eastern taste toward lighter woolens and many Florentine traders/bankers sought to develop that city's woolen industry to satisfy it. Simultaneously Italian merchants began to bypass the fairs of France, using the Atlantic route that new shipping technology made more feasible. While this certainly benefited Bruges (whose water access had not yet silted up), the new port of choice was London. As noted, the "Italian ascendancy" in the purchase and shipment of wool begins in the last quarter of the thirteenth century. Italian businessmen also invested heavily in the hinterlands of Flanders, buying cloth directly from Ghent and other industrial city merchantmanufacturers, often unfinished stuff that would then be sent to Florence and elsewhere for upgrading to suit the revolution in taste. Meanwhile, the Flemish patricians, proud of their established product, did little to satisfy new demand and chose instead to capture fully the market in the highest quality draps, a strategy that proved successful economically, but, because

and the wider mid-West (e.g. Anderson, Indiana-made batteries and spark plugs). Tires for all (including Ford's recently terminated Firestone connection) came from Akron. The later twentieth century saw an enormous shift to international sources, especially basic steel from Japan. Flanders relied throughout on English wool and on commerce from the south and east for alum and dyestuffs.

I8. T.H. Lloyd, The English Wool Trade in the Middle Ages (Cambridge, 1977), chs 2 and 3; A.R. Bridbury, Medieval English Clothmaking (London, I982). ch. 3. 
of pressures placed on fullers and weavers for ever greater productivity, created conditions leading to the famous social upheavals marking the first decades of the fourteenth century. For some merchants, trimming on quality was another avenue, but this played into the hands of Italians seeking semifinished goods. Through it all, labor costs remained higher in Flanders than in England and Florence. In the former, Flemish imports continued to outcompete town-made English products among the wealthy (for whom even the finest cloth was a lesser expenditure in any case) so the principal problem for the Flemish industry remained the high cost of English wool, much of which passed through Italian hands to reach it. And in the course of the fourteenth century, mechanized fulling, not only in England, but across the continent, did cheapen production costs for good broadcloth and Flemish urban merchant-manufacturers were slow to adapt, leaving them exposed to rural and smaller-town competition even in their own region. Florentine weavers, notoriously, were not allowed to associate, and such "modern" forms of industrial servitude as wageadvances and subsequent debt-peonage were common, assuring that labor costs remained low. In both states, political structures encouraging new exploitative production were in place. As the fourteenth century moved forward, political and ecological forces delivered the coup de grâce to an industry losing its bearings as overpopulation and climate combined to drive food prices up relentlessly, (creating not only worker despair but shrinking buying power everywhere) leading to a spiral of upheavals (including rural in the wake of the great famine of I3I7-I319) that created precarious conditions throughout the region. ${ }^{19}$

Nevertheless, urban merchant-manufacturers continued to adapt to new market conditions. As noted above, their first move was to emphasize high-quality $d r a p s$, thus searching out a market niche above the Italian competition. At the same time, rural and small-town industry, where labor costs were lower (though it is a Pirennian myth that they were unregulated) and the producers more docile, provided serges and other lower quality woolens that remained competitive. One of the key points of revisionist research is that rural and urban industry became increasingly interactive and complementary as market pressures presented the specter of decline. Clearly the devastating whirlwind of the Black Death immobilized Flemish production, as it did economic life everywhere, for a while (though there is good evidence of surprisingly rapid revitalization

19. The best summary of the Italian role in medieval economic history remains R.S. Lopez, The Commercial Revolution (Englewood Cliffs, NJ, 197I); on the impact of climatic change generally, E. Le Roy Ladurie, Le climat depuis l'an mil (Paris, I966) remains essential; see also H.S. Lucas, "The Great European Famine of I3 15, I3 16 and I3 17", in E.M. Carus-Wilson (ed.), Essays in Economic History, vol. 2 (London, 1962). 
of the English wool trade in the I350s). But it would be an error to assert, as did Pirenne, that the great textile cities simple rolled over and died, strangled by "medieval" regulations, while industrial survival and finally revitalization occurred in the unregulated countryside, creating the foundation of a "modern" economy. The story of Bruges's survival, based in its role as Flanders' window on the sea and as the region's financial center (with Italian merchants and bankers playing an inordinate role), was long contrasted with the industrial cities, especially Ghent, which supposedly slid into moribund routine. A new generation of scholarship has shown something that might have been expected if one were attuned to global processes, but not blinded by laissez-faire theory: that for every deindustrialization, there is a re-industrialization, especially if rational actors in the economic sphere can find aid in the political sphere (a combination that works particularly well if the elites in both are essentially the same, a common characteristic in most late-medieval cities).

Marci Sortor's powerful analysis of the fifteenth-century successes of Saint-Omer, a large (35,000 population) woolen producer (up to 60,000 bolts) just across the Flemish border in Artois, is instructive. Her main point is that, far from being Pirenne's "commercial dinosaurs" strangled by a medieval mode of production, Saint Omer's cloth merchants adapted to the new market circumstances of the later fourteenth and fifteenth centuries by abandoning their line of fine cloths and moving towards says, a serge, and rays, a striped fulled draps of lesser quality. Undoubtedly the overall income from woolens produced in Saint-Omer was less in 1450 than it had been in I 300 , but the town was prosperous again. No longer did their cloth travel south, but now found outlets through Hanseatic traders (via Bruges) to the Baltic and Russia. This turned out to be a more volatile market than those of yesteryear, going through waves of boom and bust. To satisfy such cycles, the industry now relied on a different kind of work force - indigenous weavers were less well and securely paid, and fullers had fewer jobs; moreover, a good number of the urban workers were temporary, migrants from the countryside or other cities ("foreigners" in the parlance of the age) who could be sent home in down time. Most importantly, Saint-Omer maintained complex relationships with woolen production in its countryside, as outworking overseen by urban merchants combined with the direct purchase of cloth from small-time merchants and craftsmen. Such complementarity, Sortor argues, makes much more sense than the image of rural-urban antagonism bequeathed by early fourteenthcentury clashes and sustained, until recently, in the historiography for much of the early modern period. Finally, politics. Municipal policy, all in regulating the industry in many ways, proved flexible and adaptable, always with an eye toward promoting the industry and assuring buyers of the quality of goods received. Certainly, the city fathers (also the leading merchants) had to wrestle with the demands of the their lifeline, the Hanse, 
and thus could not chart a completely independent course, but the town if not all its inhabitants - did well enough. ${ }^{20}$

Such an overall pattern of de-industrialization and subsequent revitalization on different terms is probably more typical than journeys into industrial oblivion. Capital, rationally administered, always seems to have a way of finding new avenues of investment if the terms - wages, raw materials (Saint-Omer even approved the use of inferior lambs' wool and pretty much abandoned English fine altogether), and property values - are right. Its ability to play "hopscotch", as I once termed it, lies at the very heart of the system.

The seventeenth-century economic decline of northern Italy, Flanders' pre-eminent heir and the next great case of pre-machine de-industrialization, offers similar parallels. Domenico Sella's research challenges much previous scholarship (though not Carlo Cipolla's brilliant 1952 article), presenting a highly nuanced picture that privileges global economic forces while factoring in culture and politics and rejecting monocausal explanation. ${ }^{2 \mathrm{I}}$ The old view that the Italian economy was stifled in the course of the sixteenth century by the Turkish presence in the Mediterranean and the opening of the New World and Atlantic routes to Asia was easily dispatched simply by careful analysis of Italian performance records. But, especially after 1620 , one can begin to speak of a de-industrialization that affected Florence, Venice, Milan, and Genoa (as well as many lesser towns) more or less equally. Italy was hardly alone

20. Marci Sortor, "Saint-Omer and the Textiles Trades in the Late Middles Ages: A Contribution to the Proto-industrialization Debate", American Historical Review, 98 (1993), pp. I475-I499. See also Yoshio Fujii, "Draperie urbaine et draperie rurale dans les Pays-Bas méridionaux au moyen âge: Une mise en point des recherches après H. Pirenne”, Journal of Medieval History, I6 (1990), pp. 88-1 I0; and John Munro, "Urban Regulation and Monopolistic Competition in the Textile Industries of the Late-Medieval Low Countries", in Erik Aerts and John Munro (eds), Textiles of the Low Countries in European History (Leuven, 1990), pp. 4 I-52. Although the problem goes far beyond this essay, Sortor's work is representative of an historiographical trend that re-examines the role of cities in the European late-medieval/early modern economy and is unwilling to accept the liberal/Marxist rejection of statist and corporative regulation as inimical to economic growth. In the end, this reinterpretation also makes this period more comparable to Chinese development, a point not lost on Wong and Pomeranz. See the brilliant discussions of this question in Steven Kaplan, La fin des corporations (Paris, 200I), especially pp. xiii-xvi and 599-6r6.

21. Domenico Sella's studies include Commercio e industria a Venezia nel secolo XVII (Venice [etc.], I96I); idem, Crisis and Continuity: The Economy of Spanish Lombardy in the Seventeenth Century (Cambridge, MA, 1979), and his most recent assessment of the problem, Italy in the Seventeenth Century (London [etc.], 1997), pp. 19-49. Carlo Cipolla's path-breaking article of 1952, "The Decline of Italy: The Case of a Fully Matured Economy", was reprinted in the outstanding collection, B. Pullan (ed.), Crisis and Change in the Venetian Economy (London, I 968), pp. I27-I 45; it also includes Sella, "The Rise and Fall of the Venetian Woolen Industry", pp. I06-I 26. Another fundamental collection is Herman van der Wee (ed.), The Rise and Decline of Urban Industries in Italy and the Low Countries (Late Middle Ages-Early Modern Times) (Leuven, I988). 
in a crisis that was "general", ${ }^{22}$ but its advanced status in manufacturing, commerce, and finance made its fall all the more striking. The northern European powers weathered the storm each in its own way, with the Dutch making the greatest strides, but in fact the reigning notion of seventeenth-century economists that there existed in the world a fixed amount of trade and that it was up to states to deploy noneconomic means to enhance their share of $i^{23}$ reflected realities in face of demographic, climatic, and resource-related (silver's depletion) calamities not dissimilar to the fourteenth century. That this second "little ice age" did not lead to total collapse is a tribute to the ability of "modern" states to quarantine, restrict travel, and provide minimal social assistance to offset the ravages of epidemic disease and famine. Ecological forces had a general effect, but cannot explain the specifics of Italy's decline.

Earlier research sought to find the "key" factor behind the process (which affected many industries beyond the core woolen and silk manufactures). One of the most popular was to "scapegoat" (as Sella puts it) the merchant/industrial elites who allegedly now sought to ape the aristocracy in record numbers by abandoning trade to become rentiers, urban and rural. "Spanish" cultural influence - hence adding a bit of nationalism - seemed the cause. The latter makes no sense since Spanish domination preceded decline by a half-century and areas free of Spanish rule, such as the Papal States and Venice, suffered as much as or more than those that were not. The simple fact is that three or four generations at the helm of business seem to be enough for most entrepreneurial families wherever and whenever capitalism has flourished, as descendants reorient toward safe investments, public service, and charitable activities (whether founding hospices or creating research foundations.) Blaming a bourgeoisie fainéante is a favorite historian's (and journalist's) pastime, whatever their politics. Witness liberal David Landes scorning the nineteenth-century French for their country's purported backwardness (a view now totally discredited); Marxist Raymond Dugrand's image of the industrialists and négociants of lower Languedoc giving up without a fight to reinvest in the vine; any number of writers on the British "climacteric"; and then the range of Weberian analyses of bureaucratic sclerosis and of ill-advised "diversification" that marked contemporary discourse on American industry in the I970s and I980s. This is not to say that businesspeople's decisions are not important, or that they are simply buffeted by forces beyond their control. But it is the context in which those decisions are taken that must be understood as central, and in the case of seventeenthcentury Italy, the main issue had to be a rational assessment of the

22. See Trevor Aston (ed.), Crisis in Europe, I 560-1660 (London [etc.], I965); Geoffrey Parker, Europe in Crisis, I598-I648 (Ithaca, NY, I979).

23. See Joseph A. Schumpeter, History of Economic Analysis (Oxford, I954), pp. 335-376. 
profitability of continuation and, for potential new industrial investors (who had always replaced the rentier-bound in the past), an assessment of the industrial future. Italy did indeed de-industrialize in the seventeenth and eighteenth centuries, but certainly the universal merchant penchant, as John Hooker put it around I600, to "creep and seek to be a gentleman" can hardly serve as a sufficient explanation for it. ${ }^{24}$

Another oft-cited internal cause perhaps has greater credence - what might be called the "too much of a good thing" thesis in which the producer guilds, as well as the merchants, having "perfected" their cloth, glass, metalware, etc. are loath to change despite shifts in demand or competitors' price advantage. The problem, of course, is when and how to alter production processes if demand remains strong even though it might be declining (and one always wonders whether the decline is not simply temporary). As we shall see, Italian manufacturers handled the problem poorly and paid dearly for it. Related to this question is the alleged power of the producer guilds and their influence on wage levels (which were high relative to Italy's rivals). Although most trades incorporated during the fifteenth and sixteenth centuries and their elaborate regulations remain to bedazzle historians, those which have received detailed study, such as the Florentine weavers, reveal a facade of power on paper, weakness vis-à-vis the merchants in reality. ${ }^{25}$ Scapegoating guild resistance is an easy road to follow, but for Italy it is a less viable explanation than in Flanders, where the producers' guilds did indeed have and physically exert their power, clearly affecting overall economic performance. But even there, larger market forces far outweighed their impact. At least one Italian industry obviously an important one - does seem to have been trammeled by structural inertia, but it had little to do with guild power. Robert Davis's work on the Arsenal, Venice's state shipbuilding enterprise and one of the largest manufacturing complexes in early modern Europe, presents a picture of management domination and subdivision of labor worthy of the Ford Motor Company, but structures of patronage, often cemented by kinship, created a rigidity and high costs of production that ultimately undermined one of Italy's proudest achievements, as the Arsenal was bypassed during the seventeenth century by new shipyards at Chatham, Marseilles, and Livorno. ${ }^{26}$ Thus, if not the guilds per se, sclerotic work structures could well have been a factor of decline.

24. J.H. Hexter, Reappraisals in History: New Views on History and Society in Early Modern Europe (New York, I96i), p. I 4.

25. Richard Rapp, Industry and Economic Decline in Seventeenth-Century Venice (Cambridge, MA, 1976); Paolo Malanima, Decadenza di un'economia cittadina: L'industria a Firenze nei secoli XVI-XVII (Bologna, I982).

26. Robert C. Davis, "Arsenal and Arsenalotti: Workplace and Community in SeventeenthCentury Venice", in Leonard Rosenband and Thomas Safley (eds), The Workplace before the Factory (Ithaca, NY, 1993), pp. 180-203. 
Sella nevertheless underlines the problem of northern Italy's comparatively high wages, which he attributes not to the power of the guilds, but to the nature of the labor market. A combination of demographic stagnation and the very diversity of the urban economies gave workers the power of exit - the possibility of locating jobs in commerce and service activities (including the burgeoning ranks of domestic servants that every "gentleman" needed to surround himself with) as well as alternative non- or weak-guild manufacturing. Travelers from elsewhere were astounded at the absence of begging and other indicators of surplus labor. Italy's wealth, in other words, though being reoriented away from manufacturing, still allowed the elites and the comfortable to live in ease and hence create jobs (if at lower pay) for most of the common folk. This phenomenon seems common to most contexts of de-industrialization unless the wealthy move out altogether, something that occurred, for example, in many American cities in the later twentieth century. Even if movement was largely nearby, effects could be devastating, especially if punctuated by the factor of race. All papers in this collection touch on the question of re-employment and we shall return to this theme below. ${ }^{27}$

"In the end, therefore, it is to [non-Italian] markets [...] that one must turn to find the key to Italy's woes", argues Sella. ${ }^{28}$ He discounts the disjunctions of mezzogiorno agriculture as a factor seriously affecting the north, saying that it was not much of a market for northern goods at any time, but rather slides over the fact that prices of southern-supplied raw silk and wool increased with agricultural setbacks (and here climatic changes were important) and thus caused at least temporary pressures before other sources could be found. International markets in the seventeenth century were volatile, to say the least (and not just the Italian world of Europe and the Ottoman Empire, but the Indian Ocean and farEastern systems as well). High politics certainly played a role as civil war racked the Ottoman heartland - a key market area - of Syria for much of the first half of the century, and the Thirty Years War devastated German markets. Moreover, mercantilist policies emerged in England and France even early in the century, having a selective impact on exports, especially glass and silk. But the main overall force remained Italians' inability to compete with the new powers of the north, England and the Netherlands (and later in the century, France, especially Languedoc woolens to the Levant). The two great sea powers had better ships and lower shipping costs, and after the Spanish wars ended, could trade unimpeded in the Mediterranean. In general, seventeenth-century customers, wherever they might be and at whatever level of income, operated on tighter budgets, thus 
appreciating the lower costs of northern products, even though their quality might be somewhat inferior.

Italians simply failed to adapt to these new market conditions. Why? Their prices remained uncompetitive. Were they pushed up artificially by high taxes? (A lament of businessmen then and now.) This may have been a factor for Venice, but most of the other states placed minimal taxes on business operations and goods. Sella does not perhaps give sufficient attention to raw material prices (which had been central to Flemish decline originally), but zeroes in on wages and manufacturing productivity. The wage issue, already discussed, was intractable due to labor market forces, not the guilds. But in one area the guilds (both the producer and merchant organizations) do bear responsibility: innovation in manufacturing technique was resisted largely on the grounds of eminently successful "tradition". High wages might have been offset by technological change, perhaps combined with different standards of quality, to achieve gains in productivity. But this was not forthcoming. As the Venetian Board of Trade put it in looking back over the century's history in fine woolens: "the true source of its decline is to be found in its reluctance to adapt to modern tastes, steeped as it is in the love of its old ways". ${ }^{29}$

As in Flanders/Artois, industrial collapse was far from total and in the long run reorientations occurred. Some industries, such as Florentine silks, survived unscathed, while others finally developed new products that proved competitive (e.g. Milanese embroidery). The main trend, as in Flanders, was toward ruralization of industry, not only in inherently rural manufactures such as the fine papers of Voltri that found important markets in the Spanish world and, significantly, in England in the eighteenth century, but in textile and metalware production as well. Although some of the latter competed with urban goods, eliciting the obligatory complaints from the towns, others, such as the enormous silkthrowing industry, which gave work to thousands of (mainly female) peasants, were perfectly complementary with urban industry. ${ }^{30}$ Thus the themes of adaptation and restructuring in Flanders/Artois and northern Italy, three centuries apart, bear marked similarities. In both, nevertheless, population in the countryside increased at the expense of the cities as industrial opportunities, in addition to agriculture, stimulated growth. Current scholarship stresses that one should not mistake this process with some rural-based "proto-industrialization", but rather see it as an adaptive development in which city, country, and, increasingly, the state interacted for industrial progress. ${ }^{3 \mathrm{I}}$

29. Idem, "Rise and Fall of the Venetian Woolen Industry", p. I23.

30. Idem, Italy in the Seventeenth Century, pp. 41-46.

31. See above all, Herman van der Wee, "Industrial Dynamics and the Process of Urbanization and De-urbanization in the Low Countries from the Late Middle Ages to the Eighteenth Century: A Synthesis", in his Rise and Fall, pp. 307-381. 
It is in this context that the experience of our third European example, the French region of lower Languedoc, becomes particularly relevant. The Languedocian woolens industry, specializing in good fulled broadcloth, but including an entire array of grades of carded woolen materials, had roots deep in the Middle Ages, but only reached its full potential in the eighteenth century, at which time it had become the largest woolenproducing region in France. Its flagship was a finely worked and relatively light draps de Levant, which was exported via jobbers in Marseilles to the échelles of the eastern Mediterranean, key ports of the Ottoman Empire. It also possessed a virtual monopoly on cloth for the military, finer stuff for the officers' uniforms and a sturdy draps for the men, gained through the good offices of Cardinal Fleury, a native son of Lodève, in I729. This happy combination meant that the dislocations of war for private commerce were offset by the heightened wartime demand for uniforms. ${ }^{32}$

The role of the state loomed large in the history of Languedocian woolens. The Ministry of War purchased military cloth directly, avoiding subcontracting except during a brief period during the Directory. But draps de Levant also benefited significantly from state assistance, having been designated by Colbert as a prime product to enhance French fortunes in foreign trade. Several manufactures royales, of which the model ville ouvrière conceded to the Maistre family at Villenouvette near the Hérault river was the most famous, set the standards for quality and production technique. Inspectors of Manufactures minutely regulated the cloth's quality, whatever its source, both at the point of production and in Marseilles. The Marseilles shippers also came under state scrutiny, and diplomatic agreements with the Turks oversaw transactions at the other end. Besides creating a documentary bonanza for historians, the policing of this trade contributed mightily to the competitive advantage draps de Levant quickly gained over its north Italian and especially English WestCountry rivals. It was indeed one of the great success stories of Colbertian economic policy. But oversight of quality, the guarantee that "Languedoc woolens" with the seal of Clermont l'Hérault or Saint-Chinian would have the same length, the same souplesse at the hidden interior of the bolt as on the outside, and its grade clearly marked was hardly a new phenomenon. The reputation of virtually all the products discussed so far from the broadcloths of Ghent or the serges of Saint-Omer to the silks of Florence or the glass of Murano found sustenance in the subsidization, regulation, and promotion by their governments, if not perhaps to the same degree as in Colbertian France. And such a role was also hardly limited to

32. Léon Dutil, Etat économique du Languedoc à la fin de l'ancien régime (1750-1789) (Paris, I9I I) provides a massive overview of the entire economy; Charles Carrière, Négociants marseillais au XVIII siècle, 2 vols (Aix-en-Provence, I977) traces the trade and its practitioners in detail; Christopher H. Johnson, "De-industrializzazione: Il caso dell'industria laniera della Linguadoca”, Quaderni storici, 52 (1983), pp. 25-56, factors in the military cloth industry. 
"pre-industrial" production (one may hope that this term is fading from our vocabulary). All one needs to do is think of the role of the American government in the building of railroads or the aircraft industry or consider the work of the postwar Japanese government in the transformation of the meaning of "made in Japan".33 Our (brief) Thatcherist age may have revived the ideology of laissez-faire and its condemnation of all who did not practice it, but in fact the long history of capitalism is much more a consideration of "profit and power" than it is the triumph of that will-o'the-wisp called the "free market".

On the other hand, over-regulation was certainly always possible and does figure in the later eighteenth-century difficulties of the Levant trade, especially in the wake of market shifts within the Ottoman Empire caused primarily by the declining buying power of the rial (a thoroughly modern problem indeed), a process which introduced growing corrupt practices at both ends (ominously "the Jews" were accused of polluting the markets of Aleppo and Constantinople). As producers and shippers alike cheated on quality to fetch lower prices, the inspectors became more assiduous, causing further consternation and mistrust. The Marseilles jobbers became the scapegoats of this drama, but in fact, market alteration - in this case having little to do with competitive products, though English fabrics from Yorkshire began to attract attention - lay at the base of decline. But if Clermont and Saint-Chinian merchants lost their luster, a new marque, that of Bédarieux, burst onto the scene in the I770s and I780s - good quality and lower priced goods produced by enterprising merchants who had taken advantage of their previously unprivileged (and hence unregulated) status to find cheaper labor, specifically weavers in the villages down the Orb valley. Clermont, and Saint-Chinian certainly put out work, but mostly to rural spinsters and were tightly regulated as to the number of weaving looms they could employ extra-muros. Simultaneously, as James Thomson has documented in his meticulous history of Clermont, merchants there - and well before the crisis - began to retire to become (a now familiar theme) landed rentiers, which obviously exacerbated the decline of their city's manufacturing vocation. ${ }^{34}$ Similar pressures arose in Saint-Chinian, where the vine also beckoned. Despite the hard work of Bédaricians, the Levant trade did decline by about a third from its peak at mid-century, the victim of global market changes.

33. See my "Capitalism and the State: Capital Accumulation and Proletarianization in the Languedocian Woolens Industry, 1700-1789", in Rosenband and Safley (eds), The Workplace before the Factory, pp. 37-62. Robert Kuttner, The End of Laissez-Faire, examines the contemporary scene, particularly the Japanese marriage of business and government.

34. James Thomson, Clermont-de-Lodève, I633-1789: Fluctuations in the Prosperity of a Languedocian Cloth-Making Town (Cambridge, 1982). It is hard to sustain it as the key cause of the region's de-industrialization because other towns, especially Bédarieux and Lodève, took up the slack. 
Military cloth production flourished, however, and did so with government help - not simply because it bought the product, but because, as a demanding customer, it forced the suppliers of Lodève to become better capitalists. As in the other old towns of the industry, agreements validated by the Estates or the Parlement regulated the number of weavers that might be sought in the countryside. Hence, to increase productivity, the most expeditious mode was to restructure the pay scales in Lodève and encourage immigration of weavers from the countryside who could be engaged outside the guild's oversight. This meant violating previous statutes, thus requiring supportive reports from the Intendancy and statute revision. When this was met with resistance, a simple step was taken (in I748): abolish the guild! Pareurs, the master cloth-finishers, were similarly treated, their corporate rights diluted. Thereafter, rural weavers flooded Lodève and a rapid re-urbanization of the industry ensued, all with the government's blessing. In the I 780 os and especially during the Consulat, officials demanded that bids for army orders be in large-scale units, hence demanding industrial consolidation. Small, and less efficient, cloth manufacturers saw themselves cut out of the business. Later, the government consistently favored fabricants who modernized their equipment, and offered subsidies to those who mechanized. The growth of large and productive firms in the defense industry also stimulated imitation in the export sector. ${ }^{35}$

Overall, then, it is not possible to speak of de-industrialization in the later eighteenth century because military cloth production more than made up the losses in the export trade, which became worse during the Revolutionary era. And later, when peace returned and army demand fell, export sales of draps de Levant revitalized to restore the equilibrium. Together, the two products went on to new heights by around i 840 , selling in the range of I 30,000 to I 60,000 bolts (pièces) for the Department of the Hérault alone, with each accounting for about half, surpassing anything achieved in the eighteenth century. Before my studies, ${ }^{36}$ historians tended to see the de-industrialization of the Midi as a straight line from the difficulties of the later eighteenth century as new fabrics (cottons) and new ways of working wool (combed-wool "nouveautés") reduced the demand for broadcloth, while that product received a new finesse from producers in Sedan and Amiens. The vital north overwhelms the moribund south as the industrialists in the latter, tails between their legs, follow the

35. Johnson, "Capitalism", and idem, "Artisans vs. Fabricants: Urban Protoindustrialization and the Evolution of Work Culture in Lodève and Bédarieux, I740-1830", Mélanges de l'Ecole française de Rome, 99 (1987), pp. 1047-1084.

36. Idem, "Il caso", in idem, Life and Death of Industrial Languedoc: The Politics of Deindustrialization (Oxford, 1995), chs I-3. 
Clermontois into the vineyard, producing an undistinguished wine for the masses. ${ }^{37}$

But what makes the case of Languedoc's de-industrialization interesting is that it is rather a bridge between the pre-machine and machine-age phenomena. For, as I show in detail in my book, the woolens towns of the Hérault did mechanize, and the production levels noted above resulted. This "industrial revolution", continuingly stimulated by both a demanding state and market forces, produced social and political consequences that in fact put the modest towns of Lodève and Bédarieux (each had populations of about I 4,000 at mid-century) at the forefront of militant trade unionism and socialism. But from the peak in the late July Monarchy, a long phase of industrial decline ensued so that by the turn of the new century "industrial Languedoc" was no more. Mono-crop Languedoc, wine-barrel to the ordinary folks of France and defended by députés $d u$ vin when prices dipped too low, became its twentieth-century persona.

How this happened and the nature of its human consequences parallel our previous examples from the pre-machine age, and also presage those of the contemporary world examined in this volume. We must begin with markets. The demand for woolens declined relative to cotton in the nineteenth century but was offset by population growth and increasingly global export possibilities. ${ }^{38}$ There is no question, however, that felted and shorn broadcloth lost market share within woolens, and within the broadcloth category, the trend was toward lighter and finer material for suits and dresses, whether in Europe or elsewhere. The staple of Languedoc, in other words, was fading as tastes changed. So why not reorient? Bédrarieux did, to some extent, but the Levant business seemed to flourish right down to the Revolution of I 848. Perhaps this niche could be theirs forever. As for the military cloth producers (Villenouvette, no longer "royal", had joined Lodève in the business as had several lesser towns), the army still wanted the staple, so there was not much inclination to innovate. And the government realized that their product's quality/cost ratio was superior to other woolens centers. Lodève held its own in competitive bidding.

The watershed era in the history of industrial Languedoc spanned the years from 1848 to 1868 . By the latter date, woolen production had dropped about one-third, and unemployment and out-migration were rife.

37. Serge Chassagne, "L'industrie lainière en France à l'époque révolutionnaire et impériale (1790-1810), in Voies nouvelles pour l'bistoire de la Révolution française. Colloque Albert Mathiez-Georges Lefebvre (30 Novembre-Ier Décembre 1974) (Paris, I978), pp. 143-167, and Gérard Cholvy, "Histoires contemporaine en pays d'oc", Annales ESC, 33 (1978), pp. 863-879 summed up the arguments.

38. Some historians argue that in 1914, the market was more "global" than it is today. Verley, L'échelle du monde, pp. 397-6i s; Herbert Feis, Europe, the World's Banker (New York, I933, repr. 1965); Gilpin, Challenge of Global Capitalism, pp. 294-296. 
Although the general trends in the market cited above continued, a variety of factors in the social and political realm contributed significantly to the decline. The disappearance of Languedocian manufacturing was anything but "natural". First, there was the power and militancy of the producers, the working class (if we may now use the term) of the two key cities. One of the great ironies in the history of capitalism is that the very power of the producing classes to shore up wages and protect working conditions (including resistance to technological innovation) through association and political action forces capital to look elsewhere for labor and/or find new sources of labor in its industrial region. In the cases of the past already analyzed, the resistance of the producer guilds (and, frankly speaking, labor historians' efforts to distinguish sharply between guilds and trade unions are surely overwrought) clearly played a role in de-industrialization, more in terms of quality control in the case of northern Italy, but to the point of revolutionary dislocation in Flanders. In Lodève and Bédarieux during the July Monarchy, worker trade-union organization (though illegal) grew rapidly, and during the Revolution of 1848 both became beacons of democratic socialism. Both also violently resisted the reaction overseen by Prince-President Louis-Napoleon Bonaparte (including the only assassination of a high public official - in I 849 at Lodève - and the bloodiest response in France to Louis-Napoleon's coup d'état at Bédarieux in $185 \mathrm{I}$ ), thus generating a shadow of doubt as to the political reliability of the region, despite the profuse declarations of support from the local notability in favor of the Second Empire. I have traced in great detail the relationship between the region and the government during this era - and all historians agree that I85I-I870 saw France's most rapid period of economic growth, a phenomenon stimulated at every turn by the state - and the conclusions seem undeniable. ${ }^{39}$ Whether motivated by the desire to promote areas where innovation seemed to result steady growth (mostly in northern France), by the specific interests of powerful figures in or close to the administration, or by a prejudice against a politically questionable region, the Imperial government, in decision after decision, failed industrial Languedoc. Rail concessions, the critical infrastructural contribution of the Second Empire to French economic history, ${ }^{40}$ were poorly routed and granted to weak (even corrupt) companies. Despite enormous efforts by the local business community, Lodève was not connected by tunnel to a nearby coal field, thus making coal expensive and seriously inhibiting the introduction of steam power. Equally important, after a brief boom during the Crimean War, the Ministry of War reallocated many orders to Sedan, Châteauroux, and elsewhere, citing -

39. Johnson, Industrial Languedoc, chs 4-8.

40. Roger Price, The French Second Empire: An Anatomy of Political Power (Cambridge, 2001), ch. 7 . 
to complete the Catch-22 - their cheaper transport costs specifically. The region did have a powerful agent in Paris to make its case in famed economist Michel Chevalier, but his silence after i 86I finally made sense when he became the first manufacturer (his wife had inherited Barbot \& Fournier, the largest firm in Lodève) to "run away", relocating in Sedan. Finally, the market for draps de Levant collapsed with the Crimean War and did not recover in part due to government inertia (naughty Bédarieux never regained favor), but also to British competition. Thus it was that social and political forces exacerbated shifting market conditions. Had policy been different, the Languedoc textile industry might have survived. Certainly in our day, sympathetic governments, responding to local action and elected national officials, have mitigated the impact of de-industrialization, as the Chrysler bailout demonstrated for southeastern Michigan. Papers in this volume analyze the vicissitudes of this relationship, from the quite positive national responses to local initiatives in the Pennsylvania anthracite region to the empty lip-service of the South African government towards the East Rand.

It must be said that the bourgeoisie of lower Languedoc did not fade quietly. Their massive (failed) campaign for a rational rail system during the I 850 s and I 860 s was followed by restructuring of the textile industry towards cheaper goods (including blankets made from shoddy), significant investment in power-looms and steam engines (despite the cost of fuel), and serious efforts to develop the Graissessac hard-coal fields (led by Montpellier Protestant capitalists). But in the end, the reorientation of capital towards the vine made more sense.

In the process, and in the vineyards as well, they sought the cheapest labor they could: a thorough feminization of the workforce in textiles was the first step (which power-looms made possible), followed by the wholesale employment of foreign, largely Spanish, labor whose willingness to accept lower wages and eschew unions fomented xenophobia, a circumstance not unfamiliar in the world today. There were, however, dramatic instances of labor solidarity with women and foreigners, perhaps also a lesson for our times. ${ }^{4}$ Still, the politics of the Left drifted increasingly towards a "regional defense", accompanied by Languedocian cultural nationalism. Some distraught workers went to the Right, to the occitanisme promoted by Charles Maurras and the Action Française, but the socialists were the main beneficiaries, along with the moderate bourse de travail programs stressing the popular linguistic and folkloric traditions of the félibrige ronge. Both essentially supported a politics of class

4I. C.H. Johnson, "Union-Busting at Graissessac: De-industrialization, Employer Strategies, and the Strike of I 894 in the Hérault Coal Basin", Journal of Social History, I9 (I985), pp. 24 I260. John Sales's riveting film, "Matewan" (1987), tells a similar story - with an equally unpleasant ending. 
reconciliation promoting the wine industry, itself dominated by huge capitalist conglomerates. As is often the case, even progressive political movements seemed to find no alternatives in a context of de-industrialization other than linking their destinies to the best hopes their restructuring economy could provide. Lelliker's paper in this collection analyzes this process brilliantly in assaying the New (post-industrial) Labour Party which, of course, could be Clinton's “new” Democrats, Schröder's Social Democrats, or Jospin's Socialists, etc.

Twentieth-century Languedoc became almost "quaint" in the eyes of northerners who in fact could not imagine the region as one of France's richest and most vital in the fairly recent past. Montpellier (let alone little Lodève and Bédarieux) was a dismal town when I started working there in the I970s. Today, as the whole world knows, it is one of France's miracle cities - insurance, high-tech industries, medical science and pharmaceuticals, luxury commerce, and indeed wine (but now AOC, not plasticbottled) give it the allure of postmodern opulence, which is visually reinforced by fabulous gentrification of the old city and the new architecture of the Polygone. Clearly a visionary new-socialist mayor, Georges Frêche (assisted by Raymond Dugrand), had something to do with this rebirth, but it is also in the very nature of capitalism to do well by doing good. Low wages, high unemployment, low real estate values in town and cheap land in the suburbs along, of course, with tax incentives and various other public subsidies, made Montpellier, "ville marchande" in the eighteenth century, a good place to do business once again and make the residents feel that capitalist investment in their future is almost a matter of noblesse oblige. Shiny Pittsburgh, glittery Cleveland, and even Detroit, are experiencing similar rebirths, with capitalists like Mike Illich (Little Caesar's Pizza and sports teams) and Peter Karmanos (Compuware, sports teams, and massive medical charity activities) of Detroit the heroes of the hour.

Although it becomes easier to draw parallels with contemporary deindustrialization (and re-industrialization) as one moves into more recent examples such as Languedoc, the essentials of earlier experiences as recounted above cast shadows of striking similarity. Everywhere, those who paid were the ordinary workers. In dealing with the problem of deindustrialization in a global, macroeconomic context one can become almost callous about the immediate consequences of its processes. But even as we penetrate these effects, there is a certain atmosphere of Greek tragedy afoot. Powerful worker organizations had perhaps contributed to the circumstances bringing about industrial decline. They then found themselves on the defensive: some, as most of the American, European, South African, Languedocian trade-union movements or the Arsenalotti of Venice, the Florentine silk guild, and the wool-weavers guild of SaintOmer did what they could to protect those who kept their jobs or made 
severance less painful, while fighting against new cheap rural or foreign labor (though sometimes trying to integrate it); others, usually minorities (though in the case of early Flanders, a majority), actually revolted either physically or with massive strikes, saying enough is enough. But to what avail? What was the outcome of the revolt of the blue-nails of the early fourteenth century, Lodève and Bédarieux's gallant struggles of the Second French Republic, the great British miners' strike of the I980s, or the League of Revolutionary Black Workers in southeastern Michigan in the early i970s? Repression, recrimination, and indeed further de-industrialization. (Dodge Main, the huge plant that harbored many of the League's most active members, was soon razed; it was replaced, in due time, by a tax-exempt, land-subsidized, two-tiered-wage-based Cadillac plant that has never had the least "labor trouble".) $4^{42}$ The divided and often desperate workers try to hang on, work sometimes to attract outside political assistance, struggle to organize runaway shop locations or foreign competitors' plants, but mostly look for jobs (or watch their children look for jobs) in less well-paid retail, service, or "independent" activities. And many must move elsewhere. These are themes of most of our papers, but they were also part of the history of Flanders/Artois (recall especially the migratory work force of fifteenth-century Saint-Omer) or of seventeenth and eighteenth-century Italy, where domestic service became a "good job", as well clearly of Languedoc where many industrial workers migrated to larger cities ending up with service or retail positions while Spaniards moved in to fill the increased demand for vine workers. ${ }^{43}$ Everywhere, labor organizations lost their potency.

Another theme, emphasized by Barchiesi and Kenny in this collection, is the dynamics of family and gender relations under the impact of deindustrialization. The keys to it are the wage differential between men and women and the patriarchal structure of most households. The family economy becomes burdened and skewed as women tend to keep or find jobs while men have greater difficulty, often forced to migrate temporarily. Whether such situations lead to male psychological distress depends on gender work-role expectations. In contexts where the notion of a male "breadwinner" is firmly established, stress, abuse, divorce, even suicide undoubtedly increase. But this is a rather late phenomenon historically, and some form of family economy where all contribute (usually around a male "head" but widows continued that role ${ }^{44}$ ) dominates most of the past, and unquestionably still prevails beyond the West. I found little evidence

42. On the League, see Heather Ann Thompson, Whose Detroit? Politics, Labor, and Race in a Modern American City (Ithaca, NY, 2000).

43. To my mind the best evocation of the human impact of de-industrialization remains the film by Michael Moore about Flint in the I980s, "Roger and Me".

44. See Janine Lanza, "Family Making and Family Breaking: Widows in Eighteenth-Century Paris” (unpublished Ph.D. dissertation, Cornell University, New York, 1997). 
of serious family disruption even in late nineteenth-century France. Probably more typical historically is the Choletais (western France) deindustrialization studied by Tessie Liu where hand-loom male linen weavers survived in low- and very high-end work, because their womenfolk, especially daughters, took in handwork from jobbers operating for the Parisian garment and articles de Paris industries, or worked in local factories doing the same. The impact on their lives, their prospects for independence, or for marriage, was significant, but their responses are difficult to document. ${ }^{45}$ Families clearly had to make enormous adjustments under the impact of economic restructuring, but those histories, still largely yet to be told, are likely to be as varied as the cultures in which they occur.

\section{CONCLUSION}

I am tempted to conclude this essay with another history that I have actually experienced, that of Detroit and its region, but space and my resolve to stress de-industrialization's deep and universal character as an essential element in the functioning of capitalism allow only a brief remark. The wild card in the history of de-industrialization (and globalization) is cultural difference: ethnicity, nationality, religion, race. Determined as we might have been to seek explanations in economics and its history in terms derived from the rationalist traditions of the European Enlightenment, including the accretion of the "political" in the classic notions of political economy, events of our time and their philosophical assessment have forced us to abandon those assumptions. Economic theory (as several recent Nobels attest) has had to search for ways to accommodate decision-making lodged in culture, and while few of us would be willing to subscribe to the more extreme notions of contingency that postmodernism has generated, there is no question that human forces beyond matrix of profit and power animate our existence. ${ }^{46}$ One might be able to write the history of racism, or nationalism, ethnic antagonism, and religious hatred, within that matrix, but they have obviously achieved a life of their own that motivates people everywhere very often to act contrary to expected economic interest. However, where economic interest along with apparent technological rationality and cultural interest coincide (at least in the short run), the direction of historical movement can be decisive.

The de-urbanization of the United States since World War II is a case in

45. Tessie Liu, The Weaver's Knot: The Contradictions of Class Struggle and Family Solidarity in Western France, 1750-1914 (Ithaca, NY, 1994).

46. My own preferences remain with the critics of postmodernism who have nonetheless also abandoned the instrumental rationalism of the Enlightenment: Habermas, Jameson, Harvey, Bourdieu. But Foucault's analysis of the power of "discourse" must be - and is being integrated with their neostructuralism. 
point (and has marked similarities to the history of the East Rand in the I990s). Thomas Sugrue's Origins of the Urban Crisis: Race and Inequality in Postwar Detroit (1996) provides a brilliant analysis of the workings of economics, politics, and race in the process of de-industrialization. What preceded the general decline of Fordist manufacturing in the final quarter of the century was the de-industrialization of cities with plant relocation in suburbs; and its human impact was decidedly unequal, with racism softening the blow for most white Americans, whatever their ethnicity, ${ }^{47}$ leaving the burden inordinately on African Americans. Arguing against simplistic themes arising in journalistic discussions of Detroit's decline that scapegoated Mayor Coleman Young and his agenda of black political power, Sugrue demonstrates in rich detail that the de-industrialization of the city itself had already occurred well before Young took office in 1973 . "Dynamic Detroit", the "arsenal of democracy" during World War II and the heart of the industrial union movement, had provided well-paying jobs and modest home-ownership for working-class citizens unequaled anywhere. And African Americans were part of the story, though as latecomers, they related more marginally. They ranked lowest historically in job quality, but the war and the role of the Fair Employment Practices Commission had improved access. Still, seniority in almost all positions fell to whites, including returning veterans. And housing, already seriously segregated from the early days of Henry Ford's "pro-Negro" policies, remained so during the wartime boom (literally including walls near Eight-Mile road), and mortgage companies, including the Federal Housing Administration and the Veterans Administration, ${ }^{48}$ refused to invest in people seen "by nature" as bad risks.

The economic and political conjuncture of the r950s unfolded in this setting. Although foreign competition was nil, the automobile companies, then many more than the "big three", engaged in possibly the most concerted campaign in history for the allegiance of the American consumer, adding "depth" advertising to pricing policies that sought to include everyone in the car market. Simultaneously, the Eisenhower administration committed unprecedented funds to a limited-access road system without parallel in the world, thus destroying public transport, both long distance and local. In order to meet the competition in the

\footnotetext{
47. The most interesting study on this topic that I know is Karen Brodkin Sacks, "How Jews became White", in Paula S. Rothenberg (ed.), Race, Class, and Gender in the United States (New York, 1998), pp. I00-II4, which focuses on the inequalities of the nation's greatest social benefits program, the Veterans' Education, Employment, and Housing Subsidies Act of 1947. 48. Thomas Sugrue, The Origins of the Urban Crisis: Race and Inequality in Postwar Detroit (Princeton, NJ, 1996); Sacks, "How Jews became White"; and for the earlier history of ethnicity and race in the city, Olivier Zunz, The Changing Face of Inequality: Urbanization, Industrial Development, and Immigrants in Detroit, I880-1920 (Chicago, IL, I982).
} 
satisfaction of the consumer mania for "wheels", ${ }^{49}$ the companies realized that they needed much more streamlined production facilities than the old, multi-floored plants of the city could provide. During the war, new suburban defense plants laid out on vast terrains with a continuous line on a single floor had proved remarkably efficient, ${ }^{\circ}$ and served as models for the massive building projects on semi-rural, relatively inexpensive land. As huge auto assembly and drive train plants relocated, suppliers and tool and dye shops followed them out of the city. Suburban housing did the same. The construction industries prospered, and workers streamed northeast to Warren and Sterling Heights, south to Taylor and Woodhaven, northwest to Novi and Milford. Warren, bordering Detroit, became the second largest city in Michigan, and everywhere, "metro"-Detroit's population surged at the expense of the city, which from its peak population approaching two million in the late I950s came in at under one million on the 2000 census. By the late I960s, the main lines of economic change were clear: not only was production being dispersed throughout the region of southeastern Michigan, but many plants still supplying the region had moved to cheap land and labor far away (particularly in rural areas of Indiana and Ohio where farm jobs were evaporating before the onslaught of agro-conglomerates) $)^{\text {sI }}$ and entire new production complexes sprang up in other regions of the country where population was exploding and trade unions weak. Everywhere, new technology ate into employment despite ever-growing sales. Jobs in southeastern Michigan had not yet begun to dry up significantly, and immigrants (now especially from the Middle East) still came to Detroit for work in auto, as had their predecessors. But if unemployment rates remained between 5 and 7 per cent for the overall population, for black Detroiters it was more than double that, and at least a quarter of young African Americans just coming onto the labor market could not find jobs in auto or anything else.

The reasons were not hard to find. Plant relocation and new technology often meant proportionately lower employment opportunities, and those with the most seniority got the jobs. Those African Americans who could qualify were faced with long commutes, for, unlike their white colleagues, they were unable to obtain mortgages for housing nearer the suburban plants, even, indeed, for a long time within the more desirable

49. See, for the politics of cars and roads, Stephen Goddard, Getting There: The Epic Struggle between Road and Rail in the American Century (New York, 1994).

50. The most famous was Ford's Willow Run B-I7 plant. See Douglas Likkel, "Willow Run" (M.A. thesis, Wayne State University, Detroit, MI, 2000).

5. Kingsley Haynes and Zachary Machunda, "Spatial Restructuring of Manufacturing and Employment Growth in the Rural Midwest: An Analysis for Indiana", Economic Geography, 63 (1987), pp. 319-333. 
neighborhoods at the edges of the city which would have put them closer to work..$^{2}$ And in the neighborhoods where housing restrictions were less prevalent, mortgages were more expensive due to "red-lining" (a term invented by the FHA) which also affected insurance rates on both homes and automobiles. The latter contributed to the cost of maintaining a car, which was virtually the only mode for most to get to work in the absence of an adequate metropolitan transit service. Sugrue's elaborate analysis of discrimination in the housing market and the step-by-step process by which the Detroit area became the most segregated in the nation is his most important contribution. It interacted with curtailed access to employment to create the conditions of life in "urban America" that are easily comparable to many cities in former colonial nations. Black radicals of the I 970 s hardly erred in terming their situation "internal colonialism". Sugrue ends his discussion with what some call the Great Rebellion, but most whites call "the riots" of July I967, in which more people were killed and injured and more property destroyed than in any other urban conflagration of an era marked by such upheavals. ${ }^{53}$ His book explains them.

Assigning responsibility for the unequal outcome of this first round of de-industrialization (in the second, more general round, many sons and daughters of the white working class - in a kind of ethnic hierarchy - paid dearly as well and headed elsewhere, especially to the South) can be tricky. The automobile corporations' economic decisions responded to market changes and opportunities followed rational pathways. Although not immune to racism in their hiring and promotion practices, they did not "conspire" to punish blacks. Nor of course did the Eisenhower administration, even though its promotion of car travel no doubt had something to do with the powerful presence of the auto giants in Washington. But federal agencies such as the VA and the FHA were staffed by Eisenhower appointees, who were even more inclined to look away as discrimination occurred in the housing market than had been the case under Truman. Overall, however, "traditional" structures of racial discrimination in union locals (especially in the booming construction trades, but even in the United Auto Workers') and above all the real-estate industry, banks, and mortgage corporations mattered most. After restrictive covenants (actual clauses preventing sales to racial and religious groups, legally recognized, in many deeds) were ruled unconstitutional in I95 $\mathrm{I}$, in a case brought by the only racially integrated law firm in Detroit, Goodman, Crockett et al., it was up to private businesses to maintain the boundaries of race. And they certainly did so. Only one Detroit lender, Standard Federal, which

52. See David Riddle, “The Rise of the 'Reagan Democrats' in Warren, Michigan, I964-1980" (unpublished Ph.D. dissertation, Wayne State University, Detroit, MI, I998).

53. Sugrue, Origins of the Urban Crisis, "Conclusion". 
had been founded by Jews to provide mortgages for Jews, served blacks in any significant number.

The Detroit example, with its profound implications for the quality of life not only for the direct victims, but for all who live with the insecurities generated by cultural discrimination and its resultant hatreds, underlines the fact that calm explanation of the economics of de-industrialization, and its place as a critical factor in the history of capitalism made ever more prominent by the forces of globalization, only begins to capture its meaning. For it is in its lived reality, especially as it is first influenced by politics, usually for the worse but sometimes to mitigate its impact, and then, more complexly, by the cultural context in which it arises, that it becomes a phenomenon of human agency - where blame can be assigned and where solutions may be sought. This is why the careful case studies in this volume, which assume the larger perspective developed in this Introduction, are so important - they grapple with the specifics of given situations and provide guidelines for action not only in their context, but in comparable situations. But this is also why, whatever its faults, the fascinating manifesto of Michael Hardt and Antonio Negri, simply entitled Empire to capture the stateless new power of the global economy, its architects, and its beneficiaries, must be read. It concludes, if vaguely, with a list of "rights" that the victims of the ongoing rhythms of economic restructuring worldwide, whom they term "the multitude", might/will (as neo-Marxists they pleasantly blur the role of agency) actualize in order to universalize its fruits. These include the right of free movement (or "global citizenship"), the right to a "social wage", and, of course, the right of "reappropriation". If the authors' notions of how the struggle is to be waged will sound too Leninist for most ears, their focus on the potential of the international nongovernmental organizations to serve as conduits for this new army of redressers seems on target. ${ }^{44}$ Above all, they underline that de-industrialization and the undulations of economic life are quintessentially human issues not to be obscured by "science", or as Foucault would have it, power-knowledge.

54. Michael Hardt and Antonio Negri, Empire (Cambridge, MA, 2000), ch. 4 ("The Multitude against Empire"). The use of the title of perhaps E.P. Thompson's most famous chapter (on the Luddites) somehow seems appropriate here. 